\title{
DARNIOS ARCHITEKTŪROS KŪRIMO URBANIZUOTOJE APLINKOJE PRIELAIDOS
}

\author{
Jūratė Kamičaitytė-Virbašienė ${ }^{1}$, Indrẻ Gražulevičiūtė-Vileniškè $\dot{2}^{2}$ \\ Architektūros ir kraštotvarkos katedra, Kauno technologijos universitetas, \\ Studentu g. 48, LT-51367 Kaunas, Lietuva \\ El.paštas: ${ }^{1 j u r a t e . k a m i c a i t y t e @ k t u . l t, 2}{ }^{2}$ razuleviciute@yahoo.co.uk.
}

Itteikta 20090419

\begin{abstract}
Santrauka. Miestų teritorinės plètros tendencijos ir populiarẻjančios pakartotinio pastatų ir teritorijų naudojimo bei kompaktiško miesto idejjos rodo, kad miestų drèkos valdymo ir gyvenimo kokybès juose gerinimo klausimai bus aktualūs ir ateityje. Ieškant būdų harmonizuoti urbanizuotos aplinkos vystymąsi, naujos kokybiškos ir prie aplinkos priderintos architektūros kūrimo miestų vidinėse dalyse ir kitose užstatytose teritorijose galimybės yra itin aktualios. Straipsnio tikslas - nustatyti darnios architektūros kūrimo urbanizuotoje aplinkoje galimybes. Siekiant šio tikslo, straipsnyje išplètojama darnios architektūros samprata, analizuojamos jos kūrimo miestų vidinèse ir priemiestinèse dalyse galimybès bei pateikiama darnios architektūros kūrimo urbanizuotoje aplinkoje hipotezè, apimanti išorinius ir vidinius veiksnius: darnų projektavimą, darnią statybą ir palankaus klimato darniai architektūrai kurti sudarymą, pasitelkiant urbanizuotos aplinkos valdymą. Darnus projektavimas suvokiamas kaip procesas, kuriuo nustatomas architektūros darnumo lygmuo ir numatomos aplinkosauginės priemonės visam objekto gyvavimo laikotarpiui. Vykdant darnią statybą urbanizuotoje aplinkoje turètų būti ieškoma būdų, kaip statyti statinius bei tvarkyti teritorijas, naudojant ekologiškas medžiagas, ir integruoti aplinkosauginį požiūrị visuose statybos ciklo etapuose. Darnios architektūros kūrimą skatinančio urbanizuotos aplinkos valdymo siekiai turètų būti orientuoti ị užstatytos aplinkos identiteto, socialinès sanglaudos, ekonominio gyvybingumo kūrimą ir palaikymą, išteklių tausojimą ir ekologinių sąlygų gerinimą.

Reikšminiai žodžiai: urbanizuota aplinka, darnus vystymasis, darni architektūra, darnus projektavimas, darni statyba, urbanizuotos aplinkos valdymas.
\end{abstract}

\section{Ivadas}

XXI a. pradžia, kaip ir XIX ir XX a., gali būti pagrịstai ivardijama globalios urbanizacijos laikotarpiu. Nors šiuolaikinès informacinès, komunikacijų ir transporto technologijos leidžia vis laisviau pasirinkti gyvenamąją vietą, dirbti namuose (nuotoliniu būdu), tačiau miestietiško gyvenimo teikiamos galimybès ir paslaugų îvairové traukia miestuose apsigyventi daugumą išsivysčiusių ir besivystančių pasaulio šalių gyventojų. Prognozuojama, kad ateityje miestuose gyvens didžioji dalis pasaulio gyventojų. Pastaraisiais dešimtmečiais suvokus, kad miestų plètra ị išorę skatina neracionalu išteklių vartojimą, kad dèl jos parandami dideli gamtinių, rekreacijai tinkamų ar produktyvių žemès ūkio paskirties teritorijų plotai, imta ieškoti būdų miestų vystymuisi harmonizuoti. Šioms problemoms dèmesio skyre daugelis tyrinėtojų ir praktikų. Pavyzdžiui, M. Sauthworth (2001) aptarè neigiamas miestų drèkos pasekmes, R. Rogers ir A. Power (2004) siūlè pakartotinio vidinių miestų teritorijų naudojimo idèją. Šiame kontekste naujos aplinką tausojančios architektūros kūrimo urbanizuotoje aplinkoje galimybès yra itin aktualios.

Straipsnio objektas - nauja architektūra urbanizuotoje aplinkoje ir jos darnaus kūrimo bei egzistavimo galimybès. Urbanizuota aplinka straipsnyje laikomos tankiai statiniais užstatytos teritorijos - miestų teritorijos, taip pat ir istoriniai centrai, miestelių teritorijos, tankiai užstatytos priemiestinès ir kitos teritorijos. 
Nauja architektūra urbanizuotoje aplinkoje laikomos nedidelio masto intervencijos pastatais užstatytose teritorijose, apimančios naujų pastatų ir statinių statybą bei jų sklypų formavimą, esamų pastatų priestatų ir antstatu statybą, naujai formuojamas atviras erdves ir esamų erdvių plètinius, esamų pastatų, statinių bei atvirų erdvių rekonstrukcijas.

Straipsnio tikslas - suformuluoti darnios architektūros urbanizuotoje aplinkoje kūrimo hipotetines nuostatas. Siekiant šio tikslo, straipsnyje pateikiama darnios architektūros samprata, aptariama darnios architektūros kūrimo reikmè ir galimybès urbanizuotoje aplinkoje, suformuluojamas darnios architektūros kūrimo urbanizuotoje aplinkoje hipotetinis modelis. Plètojant šį modelí, pateikiamos darnaus projektavimo ir darnios statybos, kaip esminių darnios architektūros kūrimo prielaidų, sampratos ir išskiriami pagrindiniai jų principai, pateikiama urbanizuotos aplinkos valdymo samprata, išskiriami bei apibūdinami pagrindiniai jo siekiai, galintys turèti įtakos darnios architektūros kūrimui.

Siekiant straipsnyje iqvardyto tikslo, buvo atlikta literatūros, kurioje aptariamos darnaus vystymosi ir darnios, su aplinka derančios architektūros kūrimo galimybès, apžvalga, buvo apžvelgti su darnios statybos, projektavimo, miestų aplinkos valdymo ir istorinès aplinkos vystymo klausimais susiję tarptautiniai dokumentai. Siekiant atskleisti urbanizuotos aplinkos kaitos tendencijas, buvo ne tik analizuota literatūra, bet ir stebėti šiandieniai miestų pokyčiai. Surinkti duomenys buvo analizuoti, palyginti, apibendrinti.

\section{Darnios architektūros samprata ir santykis su aplinka}

\subsection{Darnios architektūros samprata}

Darnus vystymasis - plètra, kai tenkinami dabartinės kartos poreikiai, neužkertant kelio savo poreikių tenkinti ateities kartoms (Report... 1987) - pastarąji dešimtmetị tapo daugelio procesų ir veiklų siekiamybe ir mokslo darbų objektu. Darnaus vystymosi koncepcija nèra statiška, taikoma vis naujiems visuomenès gyvenimo ir aplinkos aspektams ji yra nuolat plètojama. Darnus vystymasis jau nèra tapatinamas tik su ūkinès veiklos ir gamtos apsaugos tikslų suderinimu. Šiuo metu dažniausiai yra išskiriamos trys arba keturios pagrindinès darnaus vystymosi plotmès: aplinkosauginè, socialinè ir kultūrinè (arba sociokultūrinè) bei ekonominè. Dažniausiai išskiriami šie tarpusavyje susiję ir persidengiantys darnaus vystymosi principai, apimantys visas išvardintas plotmes: socialinè sanglauda ir socialinis teisingumas, gyvenimo kokybès gerinimas, kultūrinès ịvairovès, kultūros paveldo saugojimas, ekonominès gerovès užtikrinimas, tausojanti gamyba ir vartojimas, biologinès įvairovès apsauga, racionalus išteklių naudojimas ir energijos tausojimas (Benson, Roe 2000; Universal... 2001; Renewed... 2006). Darnaus vystymosi siekiai ir dimensijų pavadinimai rodo, kad darnaus vystymosi tikslu igyvendinimas liečia aplinkos ir kultūrinius išteklius, energijos gavybą ir naudojimą, ekonominius procesus, šiu dienų ir ateities visuomenes. Visi šie aspektai yra tiesiogiai ir netiesiogiai susiję su architektūros kūrimo ir gyvavimo procesais. Architektūros ir užstatytos aplinkos kūrimo ir gyvavimo kontekste itin svarbus darnaus vystymosi apibrèžime nurodytas dabarties ir ateities kartų ryšys: dabarties karta sprendžia, kurią iš praeities paveldètos užstatytos aplinkos dalị išsaugoti ateities kartoms, taip pat kuria įvairios kokybės architektūrą, kuri taps vertingu kultūriniu ištekliumi arba problema ateities kartoms. Atsižvelgiant ị minètus aspektus, galima teigti, kad architektūros darnumo siekis yra racionalus ir pagrịstas.

Išanalizavus literatūrą, buvo pastebèta, kad darnaus vystymosi principais ar jų dalimi paremtos architektūros kūrimo idèjos yra itin populiarios. Mokslinèje ir populiariojoje literatūroje, projektuose vis dažniau vartojami terminai „darni architektūra“, „ekoarchitektūra“, „ekologiška architektūra“, „žalioji architektūra“. J. Wines (2000) optimistiškai vertina darnios architektūros kūrimo galimybes. Jis teigia, kad lygiai taip pat, kaip modernizmas ir jo srovès atspindejo pramonès ir technikos pažangos amžių, taip darni architektūra atspindès aplinką tausojančių technologijų amžių. Visgi literatūros ir projektų analizè atskleidè daugelio darniais ịvardintų projektų „ekocentrizma“". Pagrindinis dèmesys projektuojant skiriamas energijos ir žaliavų sąnaudoms mažinti, eksploatavimo ekologiškumui, diegiamos naujausios aplinką tausojančios technologijos, tačiau dažnai pamirštamas architektūros estetiškumas, psichologinis priimtinumas, ryšys su aplinka. Šią problemą pripažizsta ir J. Wines (2000). Jo teigimu, architektūroje taikant aplinką tausojančias technologijas gautas rezultatas dažnai neatitinka estetikos kriterijų.

Visgi, atsižvelgiant ị sociokultūrinę darnaus vystymosi dimensiją, galima teigti, kad estetiškumas, kaip ir kontekstualumas bei psichologinis priimtinumas, taip pat turètų būti suvokiami kaip neatsiejami darnios architektūros bruožai. Darnia architektūra straipsnyje 
¿̨vardijama visapusiškai darnaus vystymosi principais paremta architektūra. Architektūros darnumas turèty būti užprogramuojamas kuriant ir išlikti per visa jos gyvavimo laikotarpi - nuo objekto projektavimo ir teritorijos paruošimo statybai darbu iki griovimo ar objekto renovacijos. Tokia architektūra turètų ne tik büti tvari, ilgaamžiška, bet ir skatinti darnu aplinkos bei visuomenès vystymąsi: skatinti ištekliu ir energijos tausojima, socialinę sanglauda ir prisideti prie gyvenimo kokybes gerinimo plačiaja prasme. Gyvenimo kokybè turètu būti suvokiama ne tik kaip fizinis patalpų komfortas, bet ir kaip dvasinis bei psichologinis architektūros kūrinio priimtinumas, susijęs su pastatų išorès ir vidaus charakteristikomis bei ryšiais su aplinka. Darnios architektūros ryšys su fizine ir socialine aplinka gali būti abipusis: architektūra gali ne tik skatinti darnų vystymąsi, darnaus vystymosi idejjoms igyvendinti palanki aplinka taip pat gali prisidèti prie darnios architektūros kūrimo. Siūloma darnios architektūros samprata išplètota 1 pav.

\subsection{Darnios architektūros kūrimo urbanizuotoje aplinkoje problemos}

Su aplinka derančios architektūros kūrimas sulaukia pakankamai daug dèmesio, tačiau darnios architektū- ros kūrimas tankiai užstatytose vidinèse miestų teritorijose ir ypač istorinejje aplinkoje vis dar yra mažai nagrinèta tema. Peržvelgus literatūrą ir ịgyvendintus projektus, pastebèta, kad aplinką tausojantys statiniai dažniausiai yra statomi gamtinèje aplinkoje ar kaimo kraštovaizdyje bei netankiai užstatytuose priemiesčiuose. Viena tokios situacijos priežasčių galètų būti minètos estetikos ir kontekstualumo problemos. Vietos klimato sąlygas išnaudojantys vėdinimo įrenginiai, saulès ar vèjo energiją naudojančios jègainès dažnai yra masyvūs inžineriniai ịtaisai, kuriuos kuriant menkai paisoma estetikos reikalavimų. Tokie įrenginiai dažniausia nedera savitose miesto teritorijose. Taip pat reikia pastebèti, kad darni su aplinka deranti architektūra tiek visuomenès, tiek architektų sąmonëje dažniausiai yra siejama su gamtine užmiesčio aplinka ir joje derančia „ekologine“ estetika - medienos, molio, apželdintų paviršių naudojimu, pabrèžtinai plastiška arba pabrěžtinai „kaimiška“ pseudoetnografine raiška. Dèl šios priežasties dažnai visapusiškai darnaus vystymosi principais paremtos architektūros kūrimas miestų vidinèse dalyse nesulaukia ne tik visuomenès palaikymo, bet ir valdžios instituciju paskatinimo. Kalbant apie istorinę užstatytą aplinką, valdžios institucijos nebent skatina laikytis paveldosaugos reika-

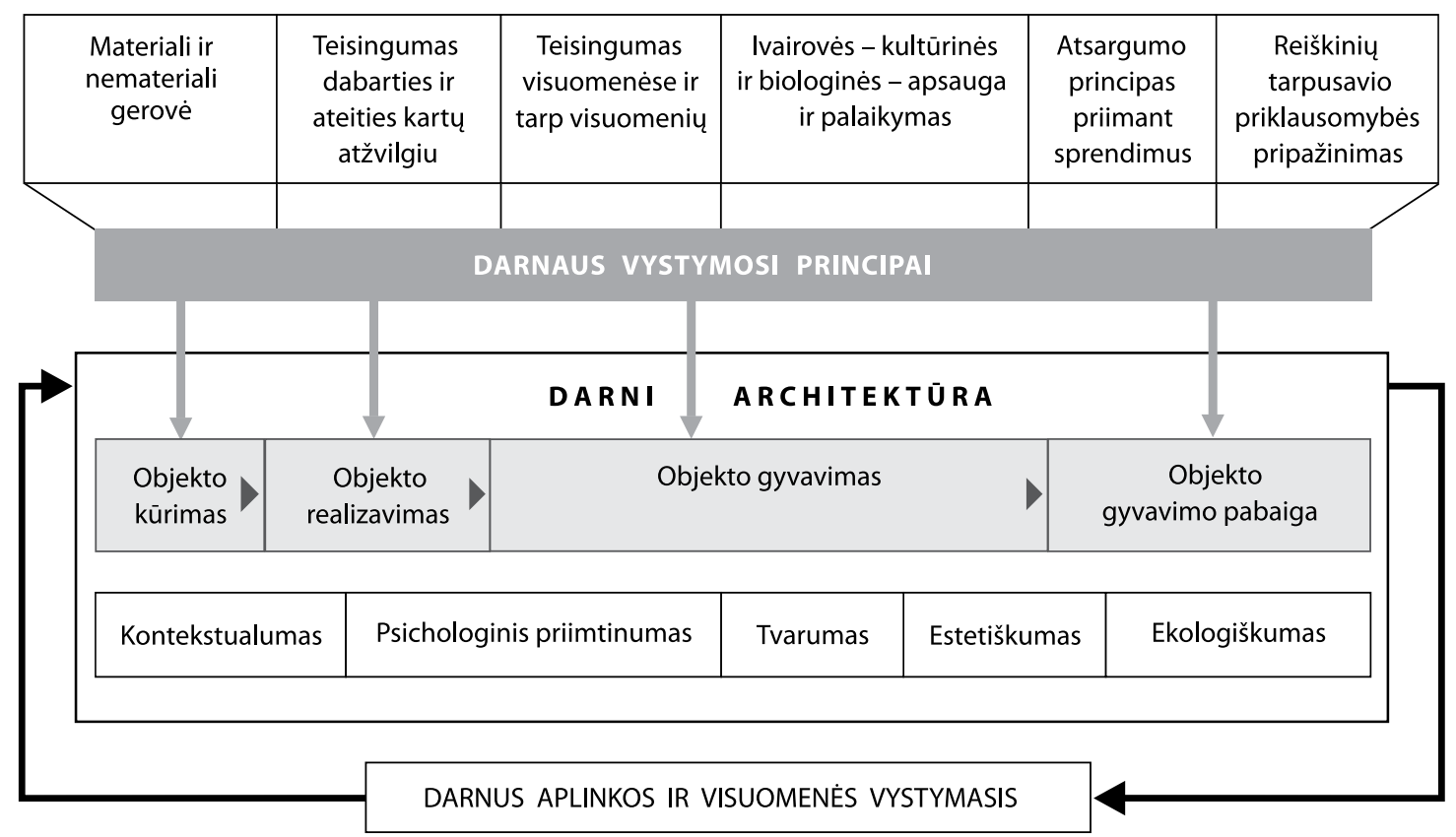

1 pav. Siūloma darnios architektūros samprata. Apibendrinti darnaus vystymosi principai pateikti remiantis D. Throsby (2002)

Fig. 1. Proposed notion of sustainable architecture. Generalized principles of sustainable development presented in the scheme are formulated by D. Throsby (2002) 
lavimų, aukštingumo apribojimų. O aplinkosaugos reikalavimai, ne mažiau svarbūs miestų centruose, yra ignoruojami.

Visgi galima daryti prielaidą, kad, plintant kompaktiško miesto, pakartotinio teritorijų ir pastatų naudojimo idèjoms, suvokus ịvairiapusę gyvenimo kokybès svarbą visuomenès vystymuisi, darnią architektūrą bus siekiama kurti ne tik užmiestyje, bet ir urbanizuotose teritorijose. Tokią prielaidą patvirtina ir daugelyje Europos, taip pat ir Lietuvos (2 pav.), miestų vykstantys procesai, pageidautini siekiant darnaus, kompaktiško miestų vystymosi: pakartotinis nenaudojamų ar neefektyviai naudojamų pastatų naudojimas, mišrus gyvenamųjų teritorijų naudojimas, gyvenamosios funkcijos grąžinimas ị miestų centrus, užstatymo sutankinimas statant priestatus ir antstatus ar naujus pastatus. Tačiau svarbu pastebèti, kad minètų procesų architektūrinè raiška būna labai ịvairios kokybès ir ne visada atspindi vietos tapatumą. Tai patvirtina poreikị siekti darnios darnaus vystymosi procesų raiškos architektūroje.

\section{Darnios architektūros urbanizuotoje aplinkoje kūrimo hipotezè}

Darni architektūra urbanizuotoje aplinkoje gali būti kuriama pavienių architektų ir užsakovų iniciatyva. Tokiais atvejais kūrimas būtų paremtas konteksto analize ir darnaus vystymosi principų taikymu projektavimo ir statybos veiklai. Tačiau yra pastebėta (Vanneste 2006), kad ịvairūs plètros projektai urbanizuotose teritorijose yra kur kas efektyviau igyvendinami, kai sulaukia ne tik valdžios institucijų, bet ir visuomenès bei vietos bendruomenès paramos. Tokiais atvejais

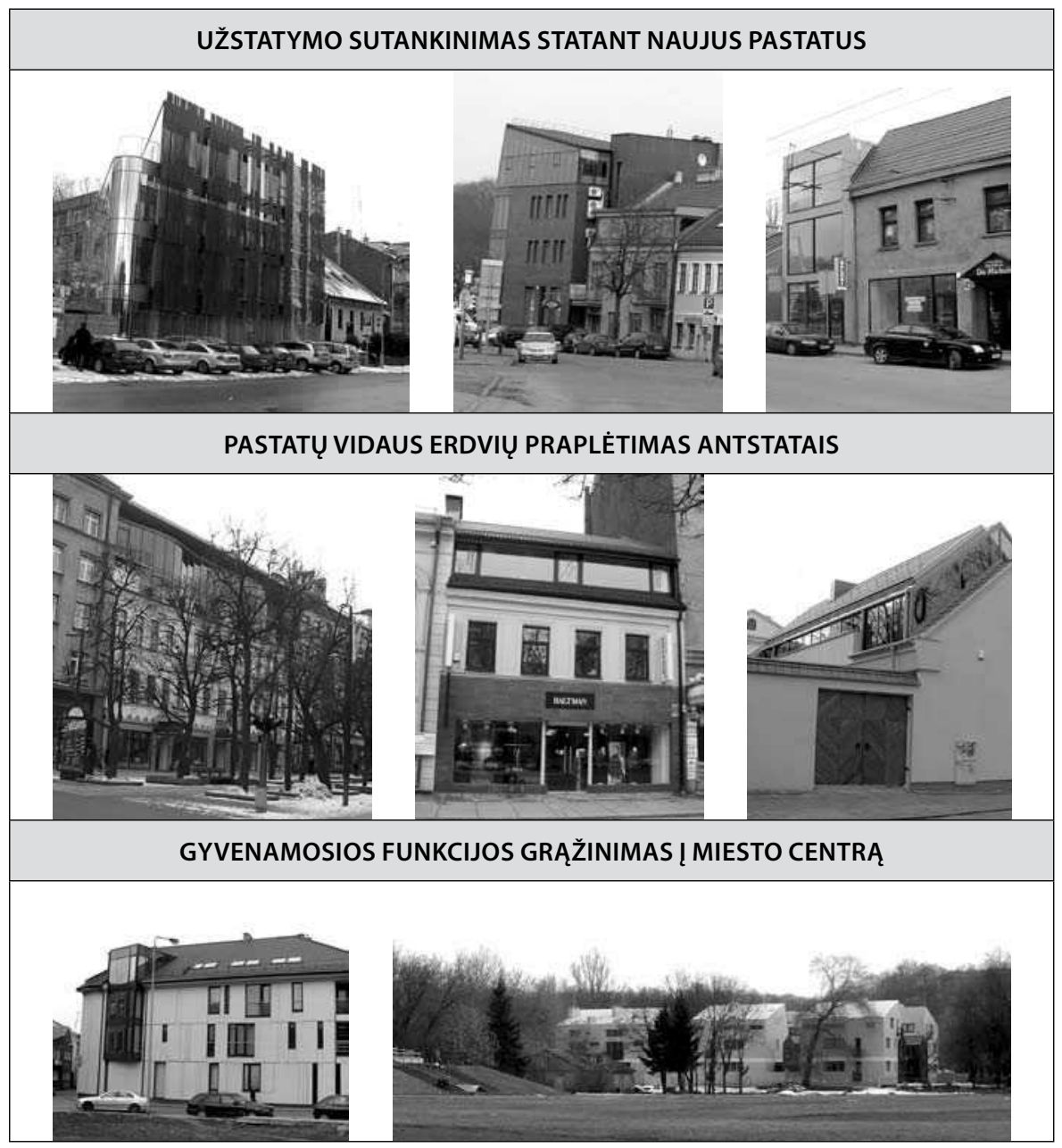

2 pav. Siekiant darnaus, kompaktiško miestų vystymosi pageidautini procesai ir ịvairi jụ architektūrinè raiška Kauno istoriniame centre (I. Gražulevičiūtès-Vileniškès nuotraukos)

Fig. 2. Processes favourable for sustainable and compact urban development and their different architectural expression in Kaunas city historic center (photographs by I. Gražulevičiūtè-Vileniškè) 
sudaromi vadinamieji „galimybių langai“, leidžiantys realizuoti ne tik architektūriškai kokybiškus, bet ir socialiai atsakingai parengtus projektus. Atsižvelgiant i minètą abipusị darnios architektūros ir fizinès bei socialinès aplinkos ryšit, straipsnyje pateikiamas hipotetinis darnios architektūros kūrimo urbanizuotoje aplinkoje modelis (3 pav.). Atsižvelgiant $i$ antrame straipsnio skyriuje suformuluotą darnios architektūros sampratą, modelyje išskiriami trys pagrindiniai darnios architektūros kūrimą urbanizuotoje aplinkoje lemiantys veiksniai: darnus projektavimas, darni statyba ir palankios aplinkos darniai architektūrai kurti sudarymas, pasitelkiant urbanizuotos aplinkos valdymą.

\subsection{Darnaus projektavimo samprata ir principai}

Darnaus vystymosi principais paremtas projektavimas yra viena svarbiausių darnios architektūros kūrimo są- lygų, nes jau šiame etape yra nustatomas objekto darnumo lygmuo (Strategy... 2008). Darnaus projektavimo principai lemia reikalavimus darniai architektūrai, $i$ kuriuos turètų būti atsižvelgta jau kuriant statinio ar teritorijos architektūrinio formavimo pradines idejas ir siekiant estetinius ir sociokultūrinius kriterijus atitinkančios ekologinių aspektų vizualinès raiškos.

Darnaus projektavimo klausimai sulaukia mokslininkų dèmesio. Pavyzdžiui, Ch. J. Kibert (2008) teigia, kad darnumo kriterijus atitinkantis projektavimas - tai projektiniai sprendimai, kuriais siekiama užtikrinti visuomenès interesų, jų lemiamų architektūrinès statybinès veiklos rezultatų - statinių - ir gamtinio pagrindo darnią koegzistenciją. K. Jong-Jin ir B. Rigdon (1998) teigia, kad esminiai darnaus projektavimo ir planavimo principai yra neatsinaujinančių aplinkos išteklių taupaus naudojimo numatymas, projektavimas laikantis

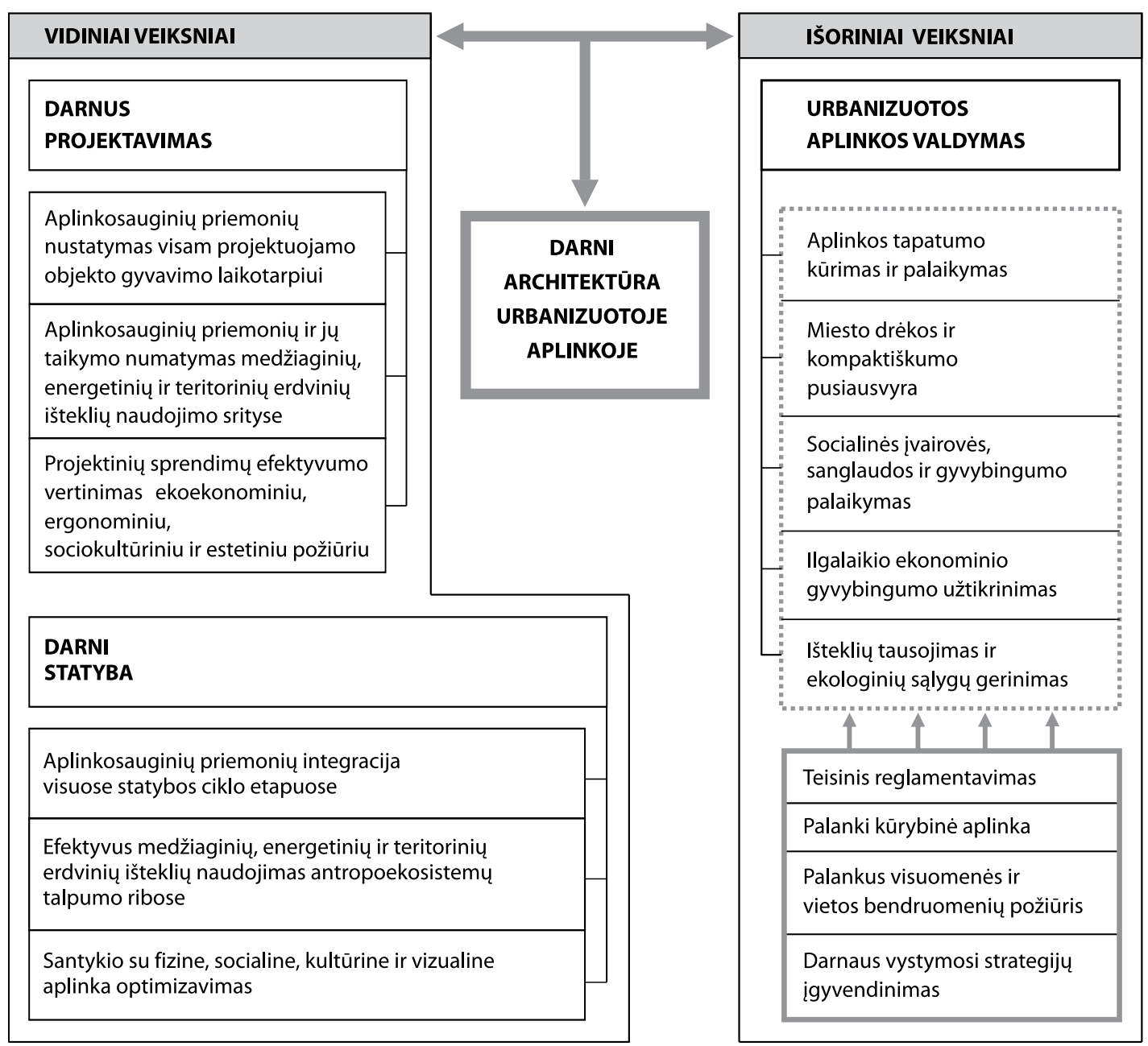

3 pav. Darnios architektūros kūrimo urbanizuotoje aplinkoje hipotetinis modelis

Fig. 3. Hypothetical model for developing sustainable architecture in the urban environment 
nuostatos, kad bet kurių išteklių, reikalingų statiniams statyti ir aplinkai tvarkyti, naudingumas yra neribotas, o keičiasi tik jų naudingumo formos bei projektavimas užtikrinant visų globalinès ekosistemos sudètinių dalių gyvybingumą. J. F. McLennan (2004) pabrèžia, kad tik darnus projektavimas, atitinkantis kartu ir ekoekonominius (ekonominiai sprendimai paremti ekosistemu talpumo rodikliais), ir sociokultūrinius (vietos savitumo palaikymas, socialinès sanglaudos skatinimas) kriterijus, lemtų darnią ateities architektūrą.

Darnaus urbanizuotos aplinkos projektavimo siekiai bei principai išdestyti ir tarptautiniuose dokumentuose. 2000 m. Europos Komisijos išleistuose Darnaus vystymosi bendruosiuose principuose nurodoma, kad planuojama ir projektuojama darni urbanizuota aplinka turi atitikti kompaktiškumo, efektyvaus miesto teritorijos naudojimo, optimalaus užstatymo tankumo, kultūros ir gamtos paveldo apsaugos, darnaus susisiekimo bei ekologiškumo principus (Decleris 2000). 2004 m. parengtas Europos Komisijos politinis dokumentas „Urbanistinès aplinkos strategijos link“ papildo šias nuostatas ir teigia, kad darnus urbanizuotos aplinkos projektavimas yra procesas, kuriuo siekiama sukurti estetišką, savitą, sveiką, stiprinančią bendruomeniškumo ir identiteto jausmą gyvenamąją aplinką, taupiai ir efektyviai naudoti žemès paviršių kaip neatsinaujinantị išteklių, plètoti multifunkcị teritorijų naudojimą ir želdynų sistemą, užtikrinti teritorijų pasiekiamumą viešuoju transportu bei transporto rūšių ịvairovę, tausoti vandenị, energiją, medžiagas, saugoti ir gausinti kultūros paveldą (Communication... 2004).

Išanalizavus literatūrą, galima išskirti šiuos darnaus projektavimo urbanizuotoje aplinkoje principus:

- Gamtiniu ir kultūriniu ištekliu apsauga ir didinimas, ịvertinant juos kaip pagrindinị projektavimo veiksni.

- Energijos ir aplinkos ištekliu tausojimas: energetiškai efektyvus teritorijos planavimas, alternatyviu energijos šaltinių, vietinių statybinių medžiagų, gaunamų iš atsinaujinančių aplinkos išteklių, perdirbtų medžiagų ir medžiagų, kurių gamybai reikia kuo mažiau energijos, naudojimo numatymas, statybinių atliekų ir naudojamų medžiagų perdirbimo bei antrinio naudojimo numatymas, esamų statinių ir teritorijų renovacija arba konversija.

- Antropoekosistemu sudetiniu daliu darnaus sambūvio užtikrinimas: poveikio vietinès ekosistemos komponentams bei jų tarpusavio ryšiams mažinimas, vietos parinkimas šalia esamos infrastruktū- ros, projektuojamų erdvių naudojimo lankstumo ir multifunkciškumo didinimas, žaliųjų erdvių plètra, žmogaus poreikių tenkinimas bioekologiniame, utilitariniame bei dvasiniame lygmenyse.

- Visu statybos ciklo etapu (ikistatybinio, statymo, postatybinio) poveikio aplinkai įvertinimas.

Apibendrinant galima teigti, kad atliekant darnų užstatytos aplinkos projektavima kuris laikomas procesu, kuriuo nustatomas statybos ir architektūros kaip statybos veiklos rezultato darnumo lygmuo, turètų būti ịvertinti žmonių poreikiai gamtinès ir kultūrinès aplinkos kaip antropoekosistemostalpumo kontekste ir turètų būti numatytos aplinkosauginès priemonès visam projektuojamo ar planuojamo objekto gyvavimo laikotarpiui. Taip pat turètų būti numatytas tų priemonių taikymas pagrindinėse žemės gelmių, paviršiaus, jo komponentų ir jų struktūrų (naudingosios iškasenos, dirvožemis, statybos vieta ir užimamas plotas, reljefas, augmenija, vanduo, kultūros paveldas, ekosistemos, miestovaizdis ir kt.) naudojimo, medžiagų ir energijos vartojimo srityse, ịvertinant taikomų priemonių ekologinị, ekonominị, ergonominị ir socialinị efektyvumą bei siekiant saugoti ir didinti aplinkos vizualinị ir semantinị potencialą.

\subsection{Darnios statybos samprata ir principai}

Statybai kaip vienai iš žmogaus ūkinès veiklos šakų, sparčiai keičiančiai gyvenamąją aplinką kiekybiniu ir kokybiniu požiūriais, ir kaip planuojamų bei projektuojamų aplinkotvarkos veiksmų igyvendinimo priemonei antropoekocentriné etiné nuostata, užkoduojama projektuojant, yra ypač aktuali. Darnios statybos klausimai ne tik nagrinejjami moksliniuose darbuose, jos tikslai ir uždaviniai pateikiami tarptautiniuose bei nacionaliniuose politiniuose ir teisiniuose dokumentuose.

Ch. Kibert (2008) teigimu, darnios statybos tikslą ir principus Tarptautinè statybos tyrimų ir inovacijų taryba suformulavo dar $1994 \mathrm{~m}$. Tarybos teigimu, tokios statybos tikslas - sveikos užstatytos aplinkos kūrimas, efektyviai naudojant aplinkos išteklius ir ekologinio projektavimo galimybes. O pagrindiniai principai: aplinkos išteklių naudojimo mažinimas, pakartotinis naudojimas, perdirbamų išteklių naudojimas, gamtos apsauga, toksinių medžiagų šalinimas, viso statybos ciklo išlaidų skaičiavimas, kokybès akcentavimas. Kituose šaltiniuose (Green... 2008; Sustainable... 2002) darnios statybos sąvoka apibrèžiama tokiais teiginiais, kaip efektyvus energijos ir išteklių naudojimas, taršos 
prevencija - pradedant statinio interjerine aplinka ir baigiant globaliniu lygmeniu, poveikio aplinkai vertinimas, siekiant statybos veiklos ir aplinkos darnios sąveikos, sisteminis požiūris visuose statybos ciklo etapuose. Šiaurès šalių ir Europos statybos bei medžio apdirbimo specialistų federacijos deklaruoja, kad darnaus vystymosi principai turètų būti taikomi visam statybos ciklui nuo statinio idejos, projektavimo, statymo iki jo sugriovimo ir atliekų tvarkymo (Statement... 2004).

Europos Sąjungos politiniuose ir teisiniuose dokumentuose darnios statybos tema gvildenama nuo 1997 m., kai Europos Komisijos pranešime apie statybos pramonès konkurencingumą akcentuota būtinybè aplinkosauginius interesus integruoti $\underset{1}{ }$ visus statybos aspektus (Communication... 1997). $2001 \mathrm{~m}$. buvo parengta Darbotvarkedarniai statybai Europoje, kurioje siūloma veiksmų programa bei rekomendacijos darniai statybos plètrai, susijusios su ekologiškų medžiagu naudojimu, pastatų energetinio efektyvumo didinimu, statybos ir griovimo atliekų tvarkymu ir statybos ciklo kainos skaičiavimu (Agenda... 2001). 2002 ir 2006 m. priimtos Direktyvos dèl energetinio pastatu efektyvumo didinimo ir kt. (Directive... 2002, 2006). 2004 m. Europos Komisijos politiniame dokumente „Urbanistinès aplinkos strategijos link“ pateikiama Europos Komisijos darnios statybos vizija XXI a. Joje teigiama, kad darni statyba yra procesas, $\mathfrak{i}$ kurị turi būti įtraukti visi dalyviai (savininkas, architektas, statybininkas, inžinierius, medžiagų tiekèjas, leidimus išduodanti institucija ir kt.) ir kuris, statant naują ir renovuojant esamą statini, integruoja funkcines, ekonomines, aplinkos ir kokybès sąlygas (Communication... 2004).

Apibendrinus Europos ir kitų šalių patirtị galima teigti, kad vykdant darnia statyba urbanizuotoje aplinkoje turètų būti ieškoma būdų, kaip statyti statinius bei tvarkyti teritorijas naudojant ekologiškas medžiagas, daugiau atsinaujinančių aplinkos išteklių, perdirbtų antrinių ir perdirbamų žaliavų bei mažiau energijos, kaip mažinti aplinkos taršą ir atliekų kiekius, kartu teikti tokią pačią ar net didesnę naudą statybos rezultatų vartotojams, kurti ne tik bioekologinius, ekonominius, ergonominius, bet ir sociokultūrinius bei estetinius kriterijus atitinkančią pastatų interjerinę bei eksterjerinę aplinką. Pagrindinè tokios statybos nuostata aplinkosauginio požiūrio integracija visuose statybos ciklo etapuose - pradedant statinio ar teritorijos projektavimu, statymu, eksploatacija ir baigiant griovimu, tinkamu atlieku tvarkymu arba statinio ar teritorijos renovacija, konversija, siekiant racionaliai panaudoti esamus statybinius išteklius. Aplinkosauginis požiūris turètų būti suprantamas kaip aplinkos išteklių (medžiaginių, energetinių, teritorinių-erdvinių) efektyvus naudojimas antropoekosistemose.

\subsection{Urbanizuotos aplinkos valdymas ir jo siekiai}

Viena pagrindinių prielaidų siekiant sudaryti palankią aplinką darniai architektūrai kurti urbanizuotose teritorijose yra nacionalinių, regioninių ir miesto lygmens darnaus vystymosi strategijų kūrimas ir igyvendinimas. İ darnų vystymąsi orientuota valstybès, regionų ir miestų raida skatintų ir darnios architektūros kūrimą. Kalbant apie darnią architektūrą, galima išskirti ir specifinius jos kūrimą skatinančius aspektus. Pavyzdžiui, palankios aplinkos darniai architektūrai kurti urbanizuotoje aplinkoje sudarymas taip pat galètų apimti miesto gyventojų ir teritorijų, kuriose Łgyvendinami projektai, bendruomenių informavimą apie darnios architektūros privalumus, ekologiškos gyvensenos propagavimą, miesto ir jo dalių savitumo, išskirtinumo pristatymą ne tik miesto svečiams, bet ir jo gyventojams. Esama situacijų, kai visiškai pasikeitus teritorijos gyventojams, po okupacijų, socialinių traumų vietos gyventojai nesuvokia savo gyvenamosios aplinkos vertingumo ir nèra linkę jos saugoti. Darnią architektūrą urbanizuotoje aplinkoje kurti paskatintu ne tik palankus visuomenès, bet ir architektų požiūris i̇ galimybę darnaus vystymosi principais paremtą architektūrą kurti vidinèse miestų dalyse, taip pat ir istorinèje aplinkoje. Tokio požiūrio formavimą būtų galima įvardinti palankios kūrybinès aplinkos sudarymu. Siekiant architektūros kokybès urbanizuotose teritorijose, vienomis iš pagrindinių priemonių išlieka teisinis reguliavimas, paremtas tiek teritorijų planavimo dokumentais, tiek įvairiais reglamentais, sankcijomis, paskatomis ir kompensacijomis. Teisinis reguliavimas gali padèti reguliuoti užstatymo aukštingumą, derinti naujų pastatų tūrius, mastelį prie esamo charakteringo užstatymo. Kompensacijų ir nuobaudų sistema gali paskatinti vystyti ekologišką statybą, saugoti kultūros paveldą.

Kompleksinis išvardintų veiksnių naudojimas galètų būti įvardijamas urbanizuotos aplinkos valdymu arba vadyba. Pastaruoju metu miestu aplinkos valdymo idejos sulaukia daug dèmesio. Pavyzdžiui, Vienos memorandume (2005 m.) skelbiama istorinio urbanizuoto kraštovaizdžio valdymo idejja. Europos Komisijos politiniame dokumente „Urbanistinès aplinkos strategijos link“ pabrèžiama integralaus požiūrio 
i miestų aplinkos valdymą svarba (Communication... 2004). Urbanizuotos aplinkos valdymo siekių spektras gali būti labai platus, pradedant švietimu ir baigiant subalansuota infrastruktūros plètra. Straipsnyje išskiriami pagrindiniai tarpusavyje susiję urbanizuotos aplinkos valdymo siekiai, galintys paskatinti darnios architektūros kūrimą: urbanizuotos aplinkos tapatumo ir išskirtinumo kūrimas, stiprinimas ir palaikymas, miestų drèkos bei kompaktiškumo pusiausvyra, socialinès ịvairovès, sanglaudos ir ilgalaikio ekonominio gyvybingumo užtikrinimas bei palaikymas, išteklių ir energijos tausojimas, ekologinių sąlygų gerinimas.

Urbanizuotos aplinkos tapatumo ir išskirtinumo kurimas, stiprinimas ir palaikymas. Vietos tapatumui palaikyti ir stiprinti yra svarbios socialiai bei ekonomiškai gyvybingos bendruomenès, kultūrinis tęstinumas, palankios ekologinès sąlygos ir daugelis kitų socialinių, ekonominių, kultūrinių bei aplinkosauginių veiksnių. Siekiant šio tikslo, labai svarbu yra saugoti ir gausinti vertingą miesto fizinę aplinką ir gerinti užstatytos aplinkos kokybę ten, kur ji yra nepakankama. Būtent fizinès aplinkos kokybès gerinimo nuostata gali paskatinti daugiabučiais gyvenamaisiais namais užstatytuose miegamuosiuose rajonuose, identitetą praradusiose priemiestinėse teritorijose statyti išskirtinès ar miesto dvasią atspindinčios architektūros gyvenamuosius, visuomeninius ir kitų paskirčiu pastatus, kurti kokybiškas viešąsias erdves. Naujos architektūros ir tapatumo bei išskirtinumo kūrimo ir palaikymo ryšys tampa itin svarbus miestų istorinèse dalyse. Siekiant išsaugoti istorinių miesto dalių charakterị, svarbu ne tik saugoti kultūros paveldą, bet ir kurti kontekstualią, kokybiš$\mathrm{ką}$, šiandienos poreikius atitinkančią architektūrą. Nauja architektūra istorinèje aplinkoje turètų atitikti jos mastelį, tūrius, pabrèžti nenutrūkstamą istorinès aplinkos raidą ir teikti informaciją apie šiuolaikinès architektūros tendencijas bei šiuolaikines medžiagas (Vienos... 2005).

Miestų drekos ir kompaktiškumo pusiausvyra. XX a. antroje pusèje dèl teritorinès miestų plètros ir gyventojų bei verslo migracijos ị priemiesčius miestų istoriniuose centruose daug pastatų ir teritorijų buvo apleista ir pradejo nykti. Gyvenamaisiais namais, pramoniniais ir komerciniais pastatais užstatytų priemiestinių teritorijų plètojimas ne tik sukèlè ekologinių problemų, bet ir pagimdè beveidžius, savo identiteto neturinčius priemiesčius. Šios problemos neliko nepastebètos ir netrukus sulaukè atsako: imtos vykdyti istorinių centrų atgaivinimo, vidinių miestų dalių užstatymo sutankinimo programos (Rogers, Power 2004; Bromley et al. 2005), pasiūlyta kompaktiško miesto idejja (Bučas 2008). Reikia pripažinti, kad net itin efektyviai išnaudojant esamus pastatus ir vidines miestų teritorijas, nepavyktų visiškai sustabdyti miestų drèkos. Darniam urbanizuotos aplinkos vystymuisi nebūtų palanki nei vien $\mathfrak{i}$ išorę nukreipta miestų plètra, nei kraštutinis miestų vidinių erdvių sutankinimas. Plètra ị išorę skatintų miestų vidinių dalių, tarp jų ir istorinių, tuštèjimą bei nykimą. Beatodairiškas užstatymo sutankinimas blogintų gyvenimo kokybę vidinèse miestų dalyse, be to, paskatintų naujų statybų bumą tiek istorinejje aplinkoje, tiek jos kaimynystėje. Miestų plètros ị išorę ir kompaktiško vystymo pusiausvyros siekis gali turèti itakos darnios architektūros kūrimui: paskatinti racionaliai tankinti užstatymą, projektuoti nedidelius, $\mathfrak{i}$ miesto audini įkomponuotus pastatus, projektuoti pastatus esamos infrastruktūros kaimynystèje, skatinti multifunkcę pastatų panaudą.

Socialinès įvairovés, sanglaudos ir gyvybingumo palaikymas. Ne tik miestų drèka, bet ir istorinių miestų dalių atgaivinimo projektai gali turèti neigiamų socialinių pasekmių. Dažnai istorinių rajonų fizinė aplinka gerinama sumenkinant jos socialinę ịvairovę bei vietos tapatumą ir išskirtinumą (Tung 2001). Istorinèse miesto dalyse ịsikuriant aukštesnių socialinių sluoksnių gyventojams, gerèjant fizinès aplinkos kokybei, kyla nekilnojamojo turto kainos. Dèl to išstumiami senieji teritorijos gyventojai, jų poreikius tenkinusị smulkųji verslą pakeičia stambūs komerciniai tinklai, viešosiose erdvèse įsivyrauja komercinè funkcija. Dažnai iš istorinių centrų išstumti gyventojai ịsikuria priemiesčiuose, kuriuose taip pat neišvengiama socialinių problemų. Tiek Jungtinių Amerikos Valstijų ir Vakarų Europos, tiek besivystančių šalių miestų priemiestinèse dalyse itin paplitęs gyventojų išsisluoksniavimas. Aukšto socialinio sluoksnio gyventojai kuriasi uždarose individualių gyvenamujų namų bendruomenėse, o žemesni visuomenès sluoksniai ir probleminès socialinès grupès dažnai įsikuria tankiai užstatytuose prastos fizinès bei architektūrinės kokybès daugiabučių gyvenamųjų namų rajonuose. Šie procesai vis labiau reiškiasi ir posovietinèse valstybėse.

Siekiant palaikyti socialinę sanglaudą, j̇vairovę ir gyvybingumą miestų centrinėse dalyse bei priemiestinèse teritorijose, svarbu pasitelkti architektūrines priemones: kurti prieinamus įvairaus dydžio būstus, gyvenamajai paskirčiai pritaikyti esamus neefektyviai naudojamus ar nenaudojamus pastatus, kurti bendravimą skatinančias viešąsias erdves, vengti uždarumą, hierarchiją teigiančios, diskriminuojančios architek- 
tūros, komercinę funkciją jungti su kultūrine ir švietimo.

Ilgalaikio ekonominio gyvybingumo užtikrinimas ir palaikymas. Ivairios miestuose vykdomos ekonominès veiklos, tokios kaip masinis turizmas ir stambių komercinių tinklų plètra, gali būti reikšmingos miestų ekonominiam gyvybingumui. Tačiau globalizacijos teikiamų spartaus susisiekimo ir kultūrinių mainų galimybių bei ekonominio nestabilumo grèsmès kontekste ilgalaikiam ekonominiam gyvybingumui yra itin svarbus miesto žmogiškaisiais ir kultūriniais ištekliais paremtas verslas. Šios veiklos skatinimas kartu gali paskatinti ir darnios architektūros kūrimą. Pavyzdžiui, nenaudojamus, tačiau kultūriniu požiūriu vertingus pramoninius pastatus galima konvertuoti, pritaikant kultūrinių industrijų poreikiams. Itin svarbu sukurti prieinamas patalpas nedidelių įmonių biurams. Šiam tikslui gali būti statomi nauji pastatai miestų vidinėse dalyse, pritaikomi esami istoriniai pastatai, panaudojamos patalpos daugiabučių gyvenamųjų namų pirmuosiuose aukštuose, taip būtų prisidedama prie kompaktiško miestų vystymo.

Ištekliu tausojimas ir ekologiniu sąlygu gerinimas. Miestai yra ne tik kultūros židiniai ir ekonomikos varomoji jèga, bet ir išteklių naudotojai bei aplinkos teršèjai (Communication... 2006). Tiek tarša, tiek miestų drèkos pasekmès tiesiogiai veikia gyvenimo kokybę miestų centruose ir priemiesčiuose. Iniciatyvos mažinti energijos ir žaliavų sąnaudas, gerinti ekologinę situaciją urbanizuotose teritorijose gali paskatinti kurti darnią architektūrą. Pavyzdžiui, siekiant žaliavų ir išteklių tausojimo, galima naudoti perdirbtas arba nesunkiai perdirbamas statybines medžiagas, statybos technologijas derinti prie vietos sąlygu (Wines 2000) bei taikyti kitus darnios statybos principus. Ekologinèms sąlygoms gerinti užterštose miestų centrinèse dalyse itin svarbi užstatytos aplinkos ekologizavimo idejja (Bučas 2008). Užstatytos aplinkos ekologizavimas yra glaudžiai susijęs su darnios architektūros kūrimu: pastatų vidinių ir išorinių sienų, stogų, balkonų apželdinimu, apželdintų erdvių įrengimu gyvenamųjų kvartalų viduje, esamų viešųjų erdvių pertvarkymu ir apželdinimu, naujų ekologiškų apželdintų viešųjų erdvių kūrimu.

\section{Išvados}

1. Darnaus vystymosi koncepcijoje integruojamos aplinkos, kultūrinių išteklių apsaugos ir plètros, ekonomikos, visuomenių vystymosi sritys yra glaudžiai susijusios su architektūra ir pagrindžia architektūros darnumo siekị. Atsižvelgiant ị kertinị darnaus vystymosi koncepcijos aspektą - dabarties ir ateities kartų ryši - darnia architektūra gali būti laikoma estetiška, kontekstuali, psichologiškai priimtina, visapusiškai darnaus vystymosi principais paremta architektūra, galinti tapti paveldu ateities kartoms. Architektūros darnumas turètų pasireikšti per visą jos gyvavimo laikotarpị ir skatinti darnų fizinès bei socialinès aplinkos vystymąsi.

2. Darnios architektūros kūrimas visuomenès, architektų ir valdžios institucijų dažniausiai yra siejamas su gamtine aplinka bei kaimo kraštovaizdžiu. Tokia nuostata lemia pabrèžtinai organišką arba pabrèžtinai „kaimišką" darnaus vystymosi principais paremtos architektūros raišką. Visgi vidinèse miestų dalyse ir kitose urbanizuotose teritorijose pasireiškiančios kompaktiškos plètros, pakartotinio pastatų naudojimo tendencijos ir ekologinès bei tapatumo kūrimo ir išsaugojimo problemos skatina ieškoti darnios architektūros kūrimo urbanizuotoje aplinkoje modelių.

3. Atsižvelgiant ị abipusị architektūros ir jos fizinès bei socialinès aplinkos ryší, daroma prielaida, kad darnios architektūros kūrimui urbanizuotoje aplinkoje paskatinti yra reikalinga architektūros kūrimą lemiančiu vidinių veiksnių - darnaus projektavimo bei statybos - ir išorinių veiksnių - $\mathfrak{i}$ darnų vystymąsi orientuoto urbanizuotos aplinkos valdymo sąveika.

- Darnaus projektavimo sprendimai bei darnios statybos rezultatai, siekiant darnios architektūros kaip objekto urbanizuotoje aplinkoje, turètų būti efektyvūs ekoekonominiu (projektavimas ir statyba remiantis antropoekosistemų talpumu), ergonominiu (projektuojamo ir statomo objekto funkcionalumas bei tinkamumas veiklai), sociokultüriniu (bendruomenès poreikių ịvertinimas ir identiteto jausmo stiprinimas, urbanizuotos terpès savitumo respektavimas bei kultūros paveldo racionalus naudojimas) bei estetiniu (išraiškingos, kompoziciškai harmoningos, originalios, vizualiai atpažistamos ir semantiškai ịprasmintos architektūros objektų kūrimas ir statyba) požiūriais ir tai turètų pasireikšti per visą architektūrinio objekto gyvavimo laikotarpi.

- Urbanizuotos aplinkos valdymas, apimantis nacionalinių, regioninių darnaus vystymosi strategijų pritaikymą ir igyvendinimą, palankaus visuomenès požiūrio į darnų užstatytos aplinkos vystymą formavimą, palankios kūrybinès aplinkos formavimą ir teisinị reglamentavimą, orien- 
tuotas ị urbanizuotos aplinkos tapatumo kūrimą ir palaikymą, miesto drèkos bei kompaktiškumo pusiausvyrą, socialinès įvairovès ir sanglaudos palaikymą, socialinio ir ilgalaikio ekonominio gyvybingumo užtikrinimą bei išteklių tausojimą ir ekologinių sąlygų gerinimą, paskatintų darnios architektūros kūrimą istorinèje aplinkoje

\section{Literatūra}

Agenda for Sustainable Construction in Europe [online]. 2001 [cited 26 November 2008]. Available from Internet: $<$ http://ec.europa.eu/enterprise/construction/suscon/ sustcon.htm $>$.

Benson, J. F.; Roe, M. H. 2000. The Scale and Scope of Landscape and Sustainability, in Landscape and Sustainability. New York: Spon Press, 1-11.

Bromley, R. D. F.; Tallon, A. R.; Thomas, C. J. 2005. City centre regeneration through residential development: contributing to sustainability, Urban Studies 42(13): 2407-2429. doi: 10.1080/00420980500379537

Bučas, J. 2008. XXI a. miestas: aplinkosaugos aspektas, in Proceedings of International Conference "Advanced Construction", Kaunas, Lithuania, 2008. Kaunas: Technologija, 27-42.

Communication towards a Thematic Strategy on the Urban Environment (COM(2004)60 final) [online]. 2004 [cited 26 November 2008]. Available from Internet: < http:// eur-lex.europa.eu/LexUriServ/site/en/com/2004/ com2004_0060en01.pdf>.

Communication on the Competitiveness of the Construction Industry (COM(97)539 final) [online]. 1997 [cited 26 November 2008]. Available from Internet: $<$ http://aei.pitt. $\mathrm{edu} / 3497 />$.

Communication on Thematic Strategy on the Urban Environment (COM(2005)718 final) [online]. 2006 [cited 26 November 2008]. Available from Internet: <http:// ec.europa.eu/environment/urban/pdf/com_2005_0718_ en.pdf $>$.

Decleris, M. 2000. The Law of Sustainable Development: General Principles. Luxembourg: European Commission.

Directive 2002/91/EC on the Energy Performance of Buildings [online]. 2002 [cited 26 November 2008]. Available from Internet: <http://www.eco.public.lu/ attributions/dg3/d_energie/energyefficient/info/directive_en.pdf $>$.

Directive 2006/32/EC on Energy End-Use Efficiency and Energy Services [online]. 2006 [cited 26 November 2008]. Available from Internet: <http://eur-lex.europa.eu/ LexUriServ/LexUriServ.do?uri=OJ:L:2006:114:0064:0064 :EN:PDF>.

Green Buildings Basics [online]. 2008 [cited 26 November 2008]. Available from Internet: <http://www.ciwmb. ca.gov/GreenBuilding/Basics.htm>.

Jong-Jin, K.; Rigdon, B. 1998. Introduction to Sustainable Design. Michigan: The University of Michigan, National Pollution Prevention Center for Higher Education.

Kibert, Ch. J. 2008. Sustainable Construction: Green Building Design and Delivery. Hoboken: John Wiley \& Sons.
McLennan, J. F. 2004. The Philosophy of Sustainable Design. Washington: Ecotone Publishing Company LLC.

Renewed EU Sustainable Development Strategy [online]. 2006 [cited 29 January 2009]. Available from Internet: $<$ http://www.env.cz/AIS/web-pub-en.nsf/\$pid/ MZPJHFJRHQPB $>$.

Report of the World Commission on Environment and Development [online]. 1987 [cited 29 January 2009]. Available from Internet: <http://www.un.org/documents/ $\mathrm{ga} / \mathrm{res} / 42 /$ ares42-187.htm $>$.

Rogers, R.; Power, A. 2004. Mažos valstybès miestai. Vilnius: Vilniaus dailès akademijos leidykla.

Southworth, M. 2001. Wastelands in Evolving Metropolis. Berkely: University of California. 2001.

Statement Concerning the Communication Towards a Thematic Strategy on the Urban Environment (COM(2004)60 final) [online]. 2004 [cited 26 November 2008]. Available from Internet:<http://ec.europa.eu/ environment/urban/pdf/stakeholder_consultation/comments_nfbww.pdf >.

Strategy for Sustainable Construction [online]. 2008 [cited 26 November 2008]. Available from Internet: $<w w w$.berr.gov. $u k / f i l e s / f i l e 46535 . p d f>$.

Sustainable Construction [online]. 2002 [cited 26 November 2008]. Available from Internet: <http://www.arch.hku.hk/ research/BEER/sustain.htm\#2.1>.

Throsby, D. 2002. Economics and culture. Cambridge: Cambridge University Press.

Tung, A. M. 2001. Preserving the World's Great Cities. The Destruction and Renewal of the Historic Metropolis. New York: Three Rivers Press.

Universal Declaration on Cultural Diversity [online]. 2001 [cited 29 January 2009]. Available from Internet: <http:// unesdoc.unesco.org/images/0012/001271/127160m.pdf $>$.

Vanneste, D. 2006. Conservation of built-up and social heritage in $19^{\text {th }}$ century industrial neighbourhoods. The impact of identity in come neighborhoods in Ghent (Flanders), in Conservation in Changing Societies. Heritage and Development. T. Patricio, K. Van Balen, K. De Jonge (Eds.). Leuven: Raymond Lemaire International Centre for Conservation, 305-312.

Vienos memorandumas tema „Pasaulio paveldas ir šiuolaikine architektūra - istorinio urbanistinio kraštovaizdžio valdymas" [interaktyvus]. 2005 [žiūrèta 2009 m. sausio 29 d.]. Prieiga per internetą: $<$ http://www.kpd.lt/lt/node/93/ pdf $>$.

Wines, J. 2000. Green Architecture. Koln: Taschen. 
PREMISES FOR DEVELOPMENT OF SUSTAINABLE ARCHITECTURE IN URBAN ENVIRONMENT

\section{J. Kamičaitytė-Virbašienè, I. Gražulevičiūtè-Vileniškè}

Abstract. Tendencies of urban territory expansion, the ideas of adaptive re-use of buildings and territories as well as the conception of a compact city demonstrate that the management of urban sprawl and improvement of the quality of life in urban areas will be still important questions in future. Possibilities to create environmentally friendly architecture of a good quality in internal territories of cities are very important in search for means of harmonizing urban development. The aim of the work is to determine the possibilities of creating sustainable architecture in the urban environment. In order to reach this aim, the notion of sustainable architecture is developed, possibilities of its creation in urbanized areas are analysed and a hypothesis for its creation in the urban environment is proposed. The hypothesis encompasses external and internal factors: sustainable design, sustainable construction and creation of preconditions favourable for developing sustainable architecture by means of management of the urban environment. Sustainable design is perceived as a process which determines the level of sustainability of architecture and means of environmental protection for the whole life cycle of a building. Sustainable construction in urban territories should search for ways to construct buildings and arrange territories using environmentally friendly materials and to integrate an environmentalistic attitude into all the stages of the construction cycle. The management of the urban environment should be oriented towards the creation and maintenance of local identity, social cohesion, economic viability as well as efficient use of resources and improvement of ecological situation in order to stimulate creation of sustainable architecture.

Keywords: urban environment, sustainable development, sustainable architecture, sustainable design, sustainable construction, management of the urban environment

\section{JŪRATE் KAMIČAITYTE்-VIRBAŠIENE்}

Dr, Assoc Prof., Dept of Architecture and Land Management, Kaunas University of Technology, Studentu g. 48, LT-51367, Kaunas, Lithuania. Tel.: (8 37) 451546.

E-mail: jurate.kamicaityte@ktu.lt

Research interests: landscape visual quality analysis, evaluation and regulation by means of environmental design, methods of planned activity or object visual impact assessment, analysis of social preferences evaluating landscape visual quality and use of the analysis results in territory planning.

\section{INDRE் GRAŽULEVIČIŪTE்-VILENIŠKE்}

Lecturer, Dept of Architecture and Land Management, Kaunas University of Technology, Studentu g. 48, LT-51367, Kaunas, Lithuania. Tel.: (8 37) 451546.

E-mail:grazuleviciute@yahoo.co.uk

Research interests: preservation and development of historic environment, economic aspects of built heritage. 